\title{
A Study on Fish Species of Sarıkum Lake in Sinop Province in the Black Sea Region
}

\author{
Öztekin YARDIM \\ Sinop University Fisheries Faculty Department of Hydrobiology TR57000 Sinop, Turkey
}

\begin{abstract}
This study was carried out between January and December 2009 in order to discover the fish species found in Sarikum Lake of Sinop Province. Sampling activities were done by using multi-filament trammel nets, scoop nets and cast nets. As a result of the sampling, 9 species (Atherina boyeri, Liza aurata, Mugil cephalus, Planiliza haematocheila, Neogobius melanostomus, Aphanius marassantensis, Gasterosteus aculeatus, Cyprinus carpio and Platichthys flesus) were determined. Results were discussed with other studies.
\end{abstract}

Keywords: Sarlkum Lake, Freshwater fish species, Sinop Province

\section{Karadeniz Bölgesi’ndeki Sinop İli, Sarıkum Gölünün Balık Türleri Üzerine Bir Araştırma}

$\ddot{O}_{z}$ : Bu çallş̧ma, Ocak ve Aralı 2009 tarihleri arasında Sinop İli Sarıum Gölü̈nde bulunan balık türlerini keşfetmek amactyla gerçekleştirilmiştir. Örnekleme faaliyetleri, çok filamentli fanyalı ağlar, kepçe ağlar ve dökme ağlar kullanılarak gerçekleştirildi. Örnekleme sonucunda 9 tür (Atherina boyeri, Liza aurata, Mugil cephalus, Planiliza haematocheila, Neogobius melanostomus, Aphanius marassantensis, Gasterosteus aculeatus, Cyp rinus carpio ve Platichthys flesus) belirlenmiştir. Sonuçlar diğer çalışmalarla tartışılmıştır.

Anahtar sözcü̈kler: Sarıkum Gölü, Tatllsu balıklarl, Sinop İli

\section{INTRODUCTION}

Lagoons are special ecosystems with great ecological importance, and they undertake many functional tasks such as regulating the water regime of the region where they exist, providing housing facilities for characteristic plant and animal communities and creating a great resource for economic, cultural, scientific and recreational purposes (Sümer and Balık, 2007).

Sarikum Lagoon Lake is located on the western coasts of the Sinop Peninsula ( $34^{\circ} 54^{\prime} 46^{\prime \prime}-34^{\circ} 58^{\prime} 22^{\prime \prime}$ E and $42^{\circ} 00^{\prime} 00^{\prime \prime}-42^{\circ} 02^{\prime} 42^{\prime \prime} \mathrm{N}$ ) in the southern Black Sea Region. This lake and its surroundings are among the important bird areas of our country and are included in the (Special Protected Areas) list with number 49. According to the National Parks Law no. 2873 , Lake Sarkum and its surroundings have attracted attention as an important ecosystem due to its sea, coastal forest, lake and sand dune and wetland area with 826 ha. For this reason, this lake was declared as a Nature Conservation Area by the Ministry of Forestry in 1987. It contains about 20.000 birds during migration.

Lake Sarkum has about 184.0 ha consisting of 102.0 ha surface and 82.0 ha marsh area. Various analyses have been performed on the water surface and waterbed of the lake. According to the results of the analyses, it has been determined that the water of the lake is brackish $(0.3-0.4 \%)$ and contains sodium, clay and moderate lime, has high organic matter and potassium ratios, has clear appearance and color, is odor-free and nonpotable, and that the lake bed is covered with $25-30 \mathrm{~cm}$ thick silage and silt. The lake water temperature has a mean annual change of $17.1^{\circ} \mathrm{C}$, reaching its lowest value by $6.9^{\circ} \mathrm{C}$ in March and its highest value by $24.0^{\circ} \mathrm{C}$ in August (Karaduman, 1993). A total area of 785 hectares was increased to a total of 826 hectares in 1991. This region first and second grade has been declared a natural protected area and all types of hunting is prohibited. The average depth of the lake does not exceed $2 \mathrm{~m}$ (Yardım et al., 2008; Sivacı et al., 2008).
Lake Sarıum is a coastal barrier lake (lagoon) formed as a result of the fact that the front side of the streams flowing into the old bay is closed by coastal dunes dragged by the waves and activated by northwest winds for many years. It is a shallow lake that is fed by small streams and flows into the sea through a small connection when the water level rises. The lake is fed by five streams. It has connections with the Keçideresi, Sarıkum Stream, inactive Karakurt Stream, Büyükdüz Stream, and Dereönü Stream which was opened by drainage to prevent lake water from overflowing (Bat et al., 2006).

In the temperature measurements performed on various dates, water temperature was measured to be $19.1^{\circ} \mathrm{C}$ and $11.5^{\circ} \mathrm{C}$, and the air temperature was measured to be $22.4^{\circ} \mathrm{C}$ and $16.3^{\circ} \mathrm{C}$.

The presence of Mediterranean tooth-carp (Aphanius marassantensis), grey mullet species (Mugil sp., Liza sp.), goby fish (Neogobius melanostomus), flounder (Platichthys flesus), gasterosteus (Gasterosteus aculeatus), sand smelt (Atherine boyeri) and cyprinus (Cyprinus carpio) in Lake Sarıkum was revealed in another studies (Şendoğan, 2006; Yardım and Erdem, 2011).

\section{MATERIAL and METHOD}

This study was carried out in 2011. Fishing supplies such as spoon-net, seine net, trammel net, blind net or gillnet, cover net, pinter, fishing line, electric shock, etc. and various types of fishponds and traps are generally used in catching fish samples. Trammel net, cover net and seine were mostly used in catching the samples. Study area is shown in Fig. 1.

Trammel nets: These are three-layer nets made of fine-porous tor network made of thin nylon thread in the middle and thick yarn on both sides of it and consisting of large-meshed trammel net, and its top line is usually equipped with cork, and its lower line is mainly equipped with lead. Samples were caught using a network of approximately $100 \mathrm{~m}$. 


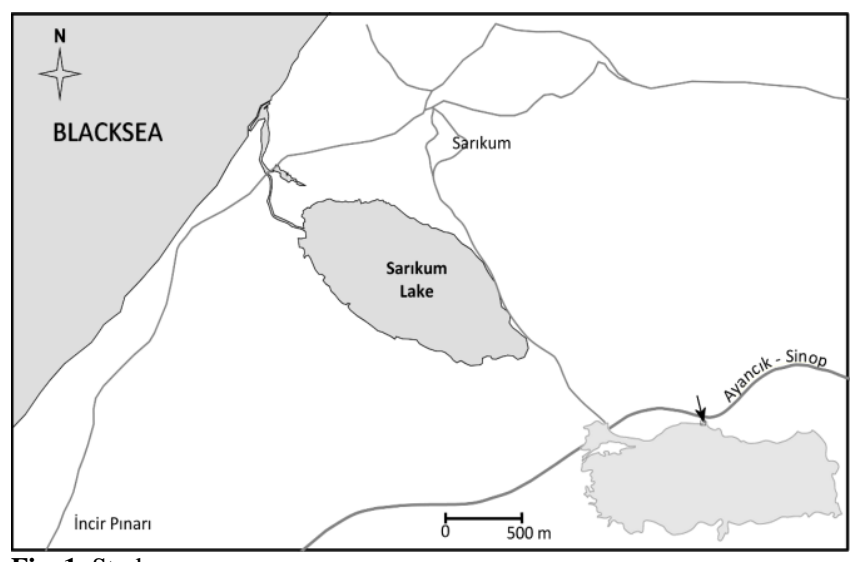

Fig. 1. Study area.

Seine nets: It is basically a kind of trawl with a bag in the middle and two wings on both sides. Seine nets are used to catch fish particularly in lakes and dams that are not too deep and slowly flowing rivers with a flat surface. A seine net with a length of approximately $30 \mathrm{~m}$ and height of 1.5-2 $\mathrm{m}$ and $2 \times 2 \mathrm{~cm}$ length of mesh was used to catch silver fish in the channel where the sea and the lake are merged in Sarıum Lake.

Cover net: These are small circular nets with different diameters. There are sinkers that allow the net to sit on the floor and small pouches for the confinement of fish on the sides of the circle, and there is a cord with 3-4 m length used to collect the nets at the center (Geldiay and Balık, 1988).

\section{SPECIES IDENTIFICATION}

The fish species obtained from the nets in the sampling performed during the study were put into formaldehyde in the study field and to perform species identification later, and they were brought to the laboratory. $100 \mathrm{~cm}$ wooden ruler for fish measurements, digital thermometer measuring both water and air temperature to detect water and air temperatures, DENSI PW-200 branded digital display weighing instrument to determine fish weights, and CANON $350 \mathrm{D}$ brand camera to monitor the fish were used. The identification of species was performed using the relevant sources (Balık and Ustaoğlu, 1984; Geldiay and Balık, 1988; Polat and Uğurlu, 2007; Bat et al., 2008) and considering the anatomical and morphological characteristics of fish (WoRMS Editorial Board, 2016; Froese and Pauly, 2017).

\section{RESULTS and DISCUSSION}

In the present study, Atherina boyeri Risso, 1810 (Sand smelt), Liza aurata Risso, 1810 (Golden grey mullet), Mugil cephalus Linnaeus, 1758 (Flathead grey mullet), Mugil soiuy Basilewsky, 1855 (Russian grey mullet), Neogobius melanostomus (Pallas, 1814) (Goby fish), Aphanius marassantensis Pfleiderer, Geiger \& Herder, 2014 (Mediterranean tooth-carp), Gasterosteus aculeatus Linnaeus, 1758 (Pungitius), Cyprinus carpio Linnaeus, 1758 (carp) and Platichthys flesus Linnaeus, 1758 (flounder) were caught.

Table 1. Fishes in the study area.

\begin{tabular}{|c|c|c|}
\hline$* \mathbf{N}$ & Species & Family \\
\hline 18 & Cyprinus carpio Linnaeus, 1758 & Cyprinidae \\
\hline 10 & $\begin{array}{l}\text { Aphanius marassantensis Pfleiderer, Geiger \& Herder, } \\
2014\end{array}$ & Cyprinodontidae \\
\hline 8 & Gasterosteus aculeatus Linnaeus, 1758 & Gasterosteidae \\
\hline 25 & Atherina boyeri Risso, 1810 & Atherinidae \\
\hline 12 & Liza aurata (Risso, 1810) & Mugilidae \\
\hline 17 & Mugil cephalus Linnaeus, 1758 & Mugilidae \\
\hline 4 & Planiliza haematocheila (Temminck \& Schlegel, 1845) & Mugilidae \\
\hline 9 & Neogobius melanostomus (Pallas, 1814) & Gobiidae \\
\hline 14 & Platichthys flesus (Linnaeus, 1758) & Pleuronectidae \\
\hline
\end{tabular}

*N: Number of fish.
Whether the sampled fish species were outside of their main habitat was evaluated based on station's connection with the sea and the fish species living in rivers supplying the field (Yardım and Erdem, 2010).

In the sampling studies, the lengths of Atherina boyeri species are between $8.5 \mathrm{~cm}$ and $11.5 \mathrm{~cm}$, and their weights are between $5.0 \mathrm{~g}$ and $13.0 \mathrm{~g}$.

The lengths of Liza aurata species are between $13.5 \mathrm{~cm}$ and 18.0 $\mathrm{cm}$, and their weights are between $30.0 \mathrm{~g}$ and $55.0 \mathrm{~g}$. It has two dorsal fin, the first one has 4 unbranched rays and no branched ray, and the second one has 1 unbranched ray and 9 branched rays, and the anal fin has 3 unbranched rays and 8 branched rays.

The lengths of Mugil cephalus species are between $15.0 \mathrm{~cm}$ and $18.5 \mathrm{~cm}$, and their weights are between $35.0 \mathrm{~g}$ and $60.0 \mathrm{~g}$. It has two dorsal fin, the first one has 4 unbranched rays and no branched ray, and the second one has 1 unbranched ray and 8 branched rays, and the anal fin has 3 unbranched rays and 9 branched rays.

The lengths of Planiliza haematocheila species are between $14.0 \mathrm{~cm}$ and $17.0 \mathrm{~cm}$, and their weights are between $30.0 \mathrm{~g}$ and $45.0 \mathrm{~g}$. It has two dorsal fin, the first one has unbranched rays and no branched ray, and the second one has 1 unbranched ray and 8 branched rays, and the anal fin has 2 unbranched rays and 9 branched rays.

The lengths of Neogobius melanostomus species are between $12.0 \mathrm{~cm}$ and $18.0 \mathrm{~cm}$, and their weights are between $20.0 \mathrm{~g}$ and $90.0 \mathrm{~g}$.

The lengths of Aphanius marassantensis species are between 5.0 $\mathrm{cm}$ and $7.5 \mathrm{~cm}$, and their weights are between $5.0 \mathrm{~g}$ and $7.0 \mathrm{~g}$. The dorsa fin has 2 hard rays and 11 soft rays, and the anal fin has 1 hard ray and 9 soft rays.

The lengths of Gasterosteus aculeatus species are between 6.5 $\mathrm{cm}$ and $7.5 \mathrm{~cm}$, and their weights are between $5.0 \mathrm{~g}$ and $8.0 \mathrm{~g}$. The dorsal fin has 3 hard rays and 12 soft rays, and the anal fin has 1 hard ray and 9 soft rays.

The lengths of Cyprinus carpio species are between $25.0 \mathrm{~cm}$ and $72.5 \mathrm{~cm}$, and their weights are between $210 \mathrm{~g}$ and $9.19 \mathrm{~kg}$.

The lengths of Platichthys flesus species are between $15.0 \mathrm{~cm}$ and $18.0 \mathrm{~cm}$, and their weights are between $40.0 \mathrm{~g}$ and $50.0 \mathrm{~g}$. The dorsal fin and anal fin do not have a hard ray, and the dorsal fin has 63 soft rays, and the anal fin has 44 soft rays.

Since Gasterosteus aculeatus species living in Lake Sarıkum has bio-indicator characteristics, it is important to examine Sarıum Lake from this aspect.

Neogobius melanostomus is one of the fish species that is wellknown by its invasiveness in the wetlands of the Black Sea basin, especially in terms of the diseases hosted by it (Özer, 2003 and 2007). Mugil soiuy the samples of the species that is a guest species in the Black Sea were obtained from Sarıkum, which are lagoons connected to the sea by precipitation. While it is in competition with local grey mullet species in the Black Sea, it has become an economic species since it is abundantly caught during its migration to our coasts between April and June.

Cyprinus carpio is a species that spreads to ponds and dams for fishing purposes, usually within the framework of a specific plan because of its economic value. It has been determined to come from the outside to Lake Sarkum. The characters belonging to culture breeds of carp such as mirrored flake, humpback, reduced and flattened intermuscular bones were observed in the samples caught from the areas where it came from the outside.

In Lake Sarkum, the population of Cyprinus carpio species is denser than other species. It is very important that the lake is first opened to hand-line fishing and monitored by the inspection to be carried out in the lake in a controlled manner and by determining the conditions by the Directorate of Nature Conservation and National Parks, and by performing the monthly determination of carp populations and investigating their effects on other fish species.

In this study that is carried out in general, fish population studies should be carried out in the areas where fish is identified, dominant species should be revealed, and undesirable species should be identified 
Moreover, it is necessary to introduce and promote culture fishing methods in our inland waters and dam lakes, to develop economic fish species, and to ensure the adaptation of non-existent economic species to the fauna in a way that they will not cause damage (Karakas and Türkoğlu, 2005).

\section{ACKNOWLEDGMENTS}

This study was supported by the Department of Hydrobiology, Fisheries Faculty, Sinop University.

\section{REFERENCES}

Balık S. and Ustaoğlu R., (1984). Inland Fisheries Systematics Laboratory Guide. Ege University Fisheries High School Publications, No: 7 Bornova, Izmir. (in Turkish).

Bat L., Yardım Ö., Sezgin M., Sıvacı R., Sıvacı A., Şendoğan E., Şahin F., Üstün F., Çulha ST., Aydemir E. and Gökkurt O., (2006). Hydrological, Ecological and Biological Analysis of SinopSarıkum Lake (Project No: S.092) Ondokuz Mayis University, Fisheries Faculty. (in Turkish).

Bat L., Erdem Y., Tırıl US. and Yardım Ö., (2011). Fish Systematics. Fen Bilimleri Nobel Bilim ve Araștırma Merkezi Publication No: 214. $2^{\text {nd }}$ edition $271 \mathrm{pp}$. (in Turkish).

Froese R. and Pauly D., (2017). FishBase. World Wide Web electronic publication. www.fishbase.org, (10/2017).

Geldiay R. and Balık S., (1988). Turkish Freshwater Fish Course Book. Ege University Faculty of Biology, Department of Hidrobiology. Books Series No: 97. 532 pp. (in Turkish).

Karakas HH. and Türkoglu H., (2005). The situation of aquatic products in Turkey and in the world. Harran University Faculty of Agricultural Journal, 9(3); 21-28 (in Turkish).

Karaduman H., (1993). Sinop National Parks and Hunting-Wildlife Chiefship Engineer's Task Force Report on the information on the taking of Sarıkum Lake to Turkey-Finland Joint Project. (in Turkish).

Özer A., (2003). Trichodina domerguei Wallengren, 1897 (Ciliophora: Peritrichia) infestations on the Round Goby, Neogobius melanostomus Pallas, 1811 in relation to seasonality and host factors. Comparative Parasitology, 70; 132-135.

Özer A., (2007). Metazoan parasite fauna of the round goby Neogobius melanostomus Pallas, 1811 (Perciformes: Gobiidae) collected from the Black Sea coast at Sinop, Turkey. Journal of Natural History, 41; 483-492

Pfleiderer SJ., Geiger MF. and Herder F., (2014). Aphanius marassantensis, a new toothcarp from the Kizılirmak drainage in northern Anatolia (Cyprinodontiformes: Cyprinodontidae). Zootaxa, 3887(5); 569-582.

Polat N. and Uğurlu S., (2007). Samsun Provincialis Fresh Water Fish Fauna. Ladik Nature and Environment Conservation Society Ladik Bookstore Research Series-1. MSc. 272 pp. March 2007 (in Turkish).

Sıvacı ER., Yardım Ö., Gönülol A., Bat L. and Gümüş F. (2008). Benthic algae of Sarıum (Sinop-Turkey) Lagoon. Journal of FisheriesSciences.com, 2(4); 592-600.

Sümer C. and Balık I., (2007). Comparison of Turkey's two Lagons Found on the Eastern and Western Mediterranean Boundary in Terms of Fishing Efficiency and Species Composition. National Water Days, 16-18 May 2007.

Şendoğan E., (2006). A Research on the Macrobenthic Fauna of Sarıkum Lake. Ondokuz Mayis University, Institute of Science and Technology, Department of Hydrobiology, MSc. 91 pp. (in Turkish).

WoRMS Editorial Board (2016). World Register of Marine Species. Available from http://www.marinespecies.org at VLIZ. Accessed 10.01.2016.

Yardım Ö., Şendoğan E., Bat L., Sezgin M. ve Çulha M., (2008). Sarıkum Gölü (Sinop) Mollusca ve Crustacea Faunası. E. U. Su Ürünleri Dergisi, 25(4); 301-309.

Yardım Ö. and Erdem Y., (2010). Invasive Fish Species in Some Lentic Waters in Sinop Province. $4^{\text {th }}$ National Limnology Symposium. 4-6 August 2010. Bolu, Turkey. (in Turkish).

Yardım, Ö. ve Erdem, Y. (2011). Sulak alanlarda Lagün Gölü Örneği: Sarıkum Gölü (Sinop) II. Türkiye Sulakalanlar Kongresi 22-24 Haziran, 2011 Kırşehir.

Received date: 20.11 .2017

Accepted date: 25.12 .2017

*Corresponding author's:

Yrd. Doç. Dr. Öztekin YARDIM

Sinop University Fisheries Faculty Department of Hydrobiology TR57000 Sinop, Turkey.

E-mail: oztekinyardim@gmail.com 